\title{
Osthole inhibits bone metastasis of breast cancer
}

\author{
Chunyu Wu ${ }^{1, *}$, Zhenping Sun ${ }^{1,}{ }^{*}$, Baofeng Guo ${ }^{1}$, Yiyi Ye ${ }^{2}$, Xianghui Han ${ }^{2}$, Yuenong Qin ${ }^{1}$ \\ and Sheng Liu ${ }^{1,2}$ \\ ${ }^{1}$ Department of Breast Surgery (Integrated Traditional and Western Medicine), Longhua Hospital, Shanghai University of \\ Traditional Chinese Medicine, Shanghai 200032, China \\ ${ }^{2}$ Pharmacology Laboratory of Traditional Chinese Medicine, Longhua Hospital, Shanghai University of Traditional Chinese \\ Medicine, Shanghai 200032, China \\ *These authors have contributed equally to this work \\ Correspondence to: Sheng Liv, email: sliv_tcm@163.com \\ Yuenong Qin, email: frank_yching@aliyun.com \\ Keywords: osthole, Cnidium monnieri (L.) Cusson, coumarin, breast cancer, bone metastasis \\ Received: September 06, $2016 \quad$ Accepted: March 21, $2017 \quad$ Published: April 11, 2017 \\ Copyright: Wu et al. This is an open-access article distributed under the terms of the Creative Commons Attribution License 3.0 \\ (CC BY 3.0), which permits unrestricted use, distribution, and reproduction in any medium, provided the original author and source \\ are credited.
}

\section{ABSTRACT}

Bone is one of the most common sites for breast cancer metastasis, which greatly contributes to patient morbidity and mortality. Osthole, a major extract from Cnidium monnieri (L.), exhibits many biological and pharmacological activities, however, its potential as a therapeutic agent in the treatment of breast cancer bone metastases remain poorly understood. In this study, we set out to investigate whether osthole could inhibit breast cancer metastasis to bone in mice and clarified the potential mechanism of this inhibition. In the murine model of breast cancer osseous metastasis, mice that received osthole developed significantly less bone metastases and displayed decreased tumor burden when compared with mice in the control group. Osthole inhibited breast cancer cell growth, migration, and invasion, and induced apoptosis of breast cancer cells. Additionally, it also regulated OPG/ RANKL signals in the interactions between bone cells (osteoblasts and osteoclasts) and cancer cells. Besides, it also inhibited TGF- $\beta /$ Smads signaling in breast cancer metastasis to bone in MDA-231BO cells. The results of this study suggest that osthole has real potential as a therapeutic candidate in the treatment of breast cancer patients with bone metastases.

\section{INTRODUCTION}

In China, the plant Cnidium monnieri (L.) Cusson has been used medicinally for centuries. The dried fruits of C. monnieri have been used widely in Chinese herbal prescriptions for the treatment of such conditions as itchy skin and eczema, pain in female genitalia, sexual dysfunction, and to promote bone regulation [1-4]. In traditional Chinese medicinal, C. monnieri is found in many formulations, such as Bushen Zhuanggu, BuGuZhi Wan, Wenshen Zhuanggu, and FaZhi Heidou. In particular, the Bushen Zhuanggu formula has been clinically prescribed for many years as an alternative therapy for the treatment of metastatic breast cancer. In a retrospective cohort study, the Bushen Zhuanggu formula was used clinically as an adjuvant in breast cancer patients with bone metastases. Patients receiving the formula showed improvements in bone pain, reduction in the incidence of bone-related events, and a demonstrated delay in and decreased number of osteolytic lesions. Our previous studies have also documented that, in mice, a Chinese formula including $P$. corylifolia-C. monnieri inhibits bone metastasis in breast cancer, possibly due to alterations in the OPG/RANKL/RANK system $[5,6]$.

Osthole (7-methoxy-8-isopentenoxycoumarin) is a coumarin-derivative extract of $C$. monnieri that has been shown to inhibit many pathological disorders, such as allergies, inflammation, HIV activity, diabetes, as well as provide protective effects for the liver [7-12]. It can also improve learning and memory $[13,14]$. In addition, osthole has been reported to have an inhibitory effect on multiple 
types of cancer, including breast cancer, cervical cancer, hepatic carcinomas, leukemia, and lung cancer [15-19]. The mechanism underlying these inhibitory effects is currently under investigation. Osthole's inhibition of the invasion of breast cancer cells in vitro has been demonstrated by research from several groups, including ours [15, 20]. Additionally, osthole has been implicated in the regulation of bone metabolism, and has been shown to have the ability to suppress bone loss and promote bone healing through controlling the differentiation of both osteoblasts and osteoclasts [21, 22]. Together, these results suggest the potential for osthole as a therapeutic candidate for inhibiting in vivo bone metastasis. In this study, we utilized a mouse model to investigate whether or not osthole could inhibit the metastasis of human breast cancer cells to bone.

\section{RESULTS}

\section{Osthole inhibited bone metastasis in mice}

Mice with osseous metastases were divided randomly into 2 groups. To determine if osthole treatment could reduce osseous metastases, one group of mice was treated orally twice weekly with osthole $(5.25 \mathrm{mg} / \mathrm{kg})$, and the other group was treated identically with vehicle. After six weeks of treatment with osthole, the tumor metastasis rate to bone was suppressed by $40 \%$ on average and the number of metastatic lesions was reduced by approximately $57 \%$ when compared to vehicle-treated mice (Figure 1A-1E). We then evaluated the bones for metastatic lesions histologically and calculated the number of tumor cells present in the lesions. Osthole administration resulted in a significant reduction in tumor infiltration and an average $35 \%$ decrease in the percentage of tumor cells in metastatic lesions, when compared to vehicle-treated mice (Figure 1F/1G).

\section{Osthole regulated genes for bone metastasis and metabolism in mice}

In order to examine the means by which osthole treatment reduced metastatic growth, we harvested metastatic bone lesions and analyzed the gene products associated with bone metastasis and metabolism using real-time quantitative PCR (RT-qPCR) and western blotting. The resulting data revealed that, in osseous metastatic lesions, osthole significantly increased osteoprotegerin (OPG) and reduced interleukin-8 (IL8), macrophage colony-stimulating factor (M-CSF) and parathyroid hormone-related peptide (PTHrP) protein expression (Figure 2A/2B). Interestingly, we found that the expression of bone-related mRNAs were similar to those proteins (Figure 2C). Together, our data suggest that the inhibitory effect of osthole on breast cancer bone metastasis may be due to the promotion of OPG and the inhibition of IL-8, M-CSF and PTHrP gene expression in tumor-bearing mice.

\section{Osthole suppressed cell viability and proliferation of MDA-231BO cells}

We found that osthole significantly reduced tumor infiltration in metastatic lesions in vivo. In addition, osthole significantly reduced proliferation of human breast cancer MDA-MB 435 cells, but did not inhibit MCF-7 cell proliferation [15, 23]. To determine whether or not the reduction in osseous metastases was the result of diminished cellular viability, we used MTT assays to measure the effects of osthole on MDA-231BO cell viability. As shown in Figure 3A, MDA-231BO cells treated for $24 \mathrm{~h}$ with osthole at a concentration greater than or equal to 40 $\mu \mathrm{M}$ displayed significant inhibition in cellular viability in vitro. To further examine the effect of osthole on MDA-231BO cell proliferation, we carried out colony formation assay to evaluate its antiproliferative effects. As shown in Figure 3B/3C, concentrations of osthole greater than or equal to $40 \mu \mathrm{M}$ significantly inhibited the proliferation of breast cancer cells in vitro. The disparity between previous study and our current results could be due to differences among the cell lines examined [see Supplementary Materials]. cell proliferation and reduces cell viability in human breast cancer cell bone-seeking subclone MDA-231BO.

\section{Osthole impaired the migration and invasion of MDA-231BO cells}

As described previously, osthole significantly reduced ER-positive breast cancer cell line MCF-7 migration [15]. Despite this, it is unclear whether osthole could inhibit cell migration in ER-negative breast cancer cell line MDA-231BO or not. We determine the role of osthole in cellular migration. MDA-231BO cells were treated with osthole for $24 \mathrm{~h}$. Following treatment, the ability of MDA-231BO cells to migrate into wounds created by scratching confluent cells with a pipette tip was measured. As shown in Figure 4A/4C, MDA-231BO cells treated with osthole at the indicated concentrations displayed significant delays in wound closure resulting from diminished cellular migration. Quantification of wound size revealed that treatment of cells with osthole at a concentration of $80 \mu \mathrm{M}$ inhibited wound closure by an average of $60 \%$ as compared with vehicle-treated cells. Additionally, we assessed the inhibition of osthole on cell invasion using the transwell assay. The resulting data showed that osthole at concentrations greater than or equal to $40 \mu \mathrm{M}$ significantly reduced cell invasion (Figure 4B/4D).

\section{Osthole induced apoptosis in MDA-231BO cells}

Previously study shown that osthole induced cell apoptosis in breast cancer cell line MDA-MB 435 [23]. 
A

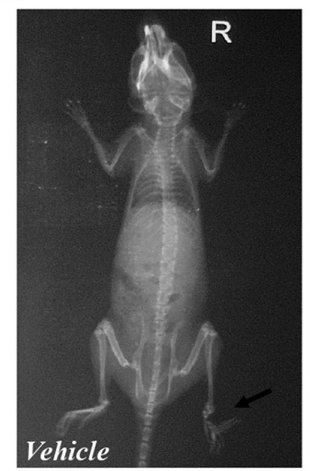

C
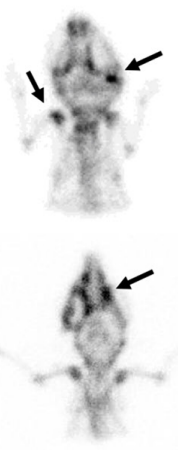

$\mathbf{E}$

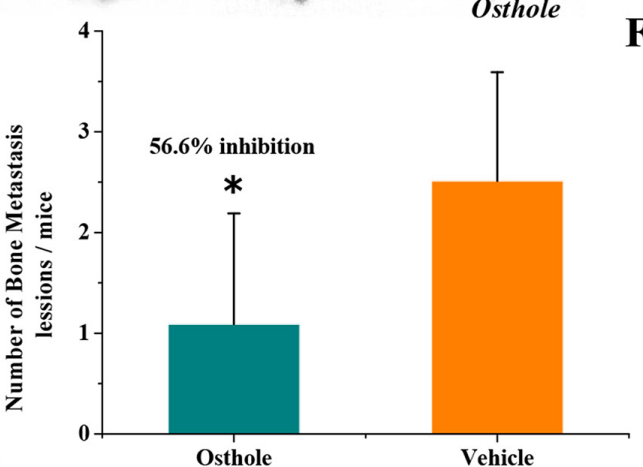

G
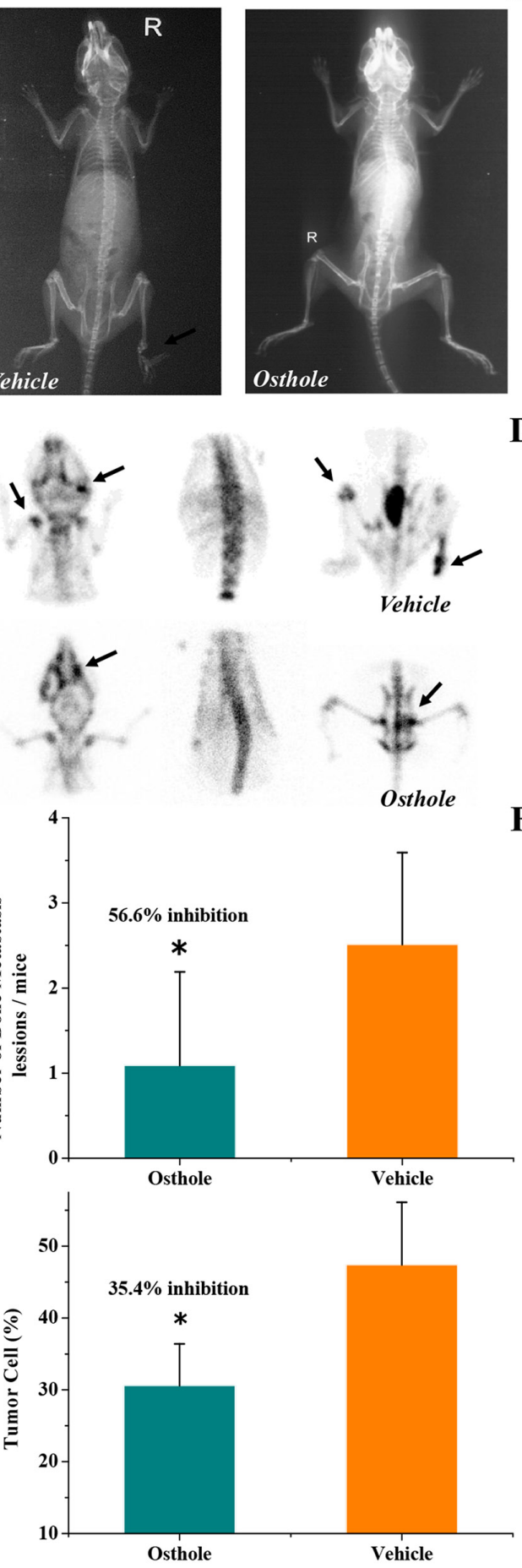

B
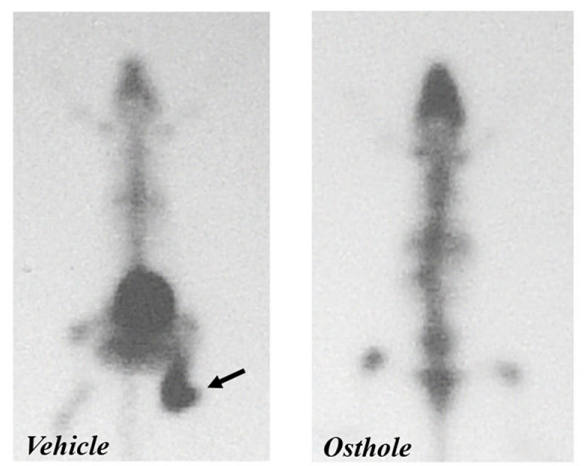

D

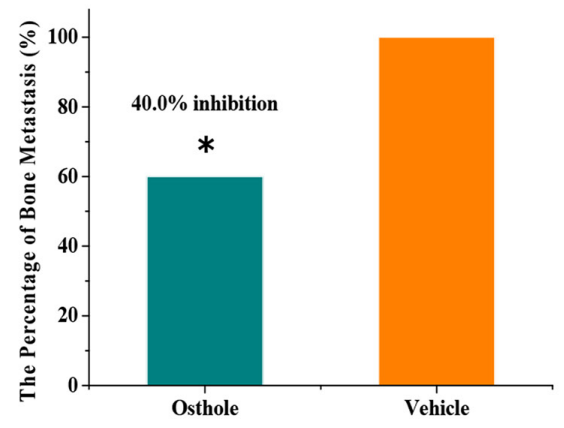

F
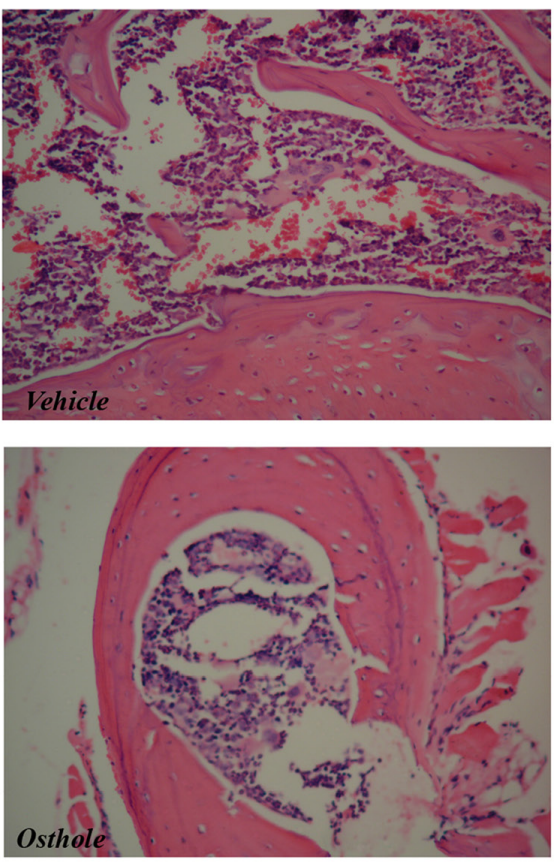

Figure 1: Osthole-mediated inhibition of breast cancer bone metastasis in mice. (A) Radiograph images. (B) Whole-body bone scintigraphy images. (C) Pinhole bone scintigraphy images (arrows indicate sites of bone metastases). (D) Osthole diminished the incidence of bone metastasis ( ${ }^{*} p<0.05$ by the Fisher exact test). (E) Osthole reduced bone metastasis lesions $\left({ }^{*} p<0.05\right.$ by ANOVA). (F) Representative images of osseous metastases. (G) Quantitative histomorphometry measurement of tumor burden in bone lesions $\left({ }^{*} p<0.05\right.$ by ANOVA). Mice received an intracardiac injection of MDA-231BO cells, resulting in osseous metastases as detected by radionuclide bone scintigraphy and X-ray imaging within 2 weeks of tumor inoculation. The mice were then randomly divided into 2 groups $(\mathrm{n}=10$ per group) that received either oral osthole $(5.25 \mathrm{mg} / \mathrm{kg})$ or vehicle twice weekly for 6 weeks. Every two weeks following inoculation, bone metastasis was evaluated by in vivo imaging with radiographs and radionuclide bone scintigraphy. Mice were sacrificed at the end of treatment, and metastatic bone lesions, observed by radionuclide scintigraphy and radiography, were sectioned and sent for H\&E staining (magnification: 200X). 
To confirm osthole's role in the regulation of cell apoptosis in MDA-231BO cells, we performed flow cytometric analyses specific for apoptosis. Consist with previous studies, treatment with osthole for $24 \mathrm{~h}$ significantly induced cell apoptosis in MDA-231BO cells when the concentrations of osthole were greater than or equal to 40 $\mu \mathrm{M}$ (Figure 5). Together, these data suggest that osthole induces apoptosis in MDA-231BO cells.

\section{Osthole inhibited the TGF- $\beta /$ Smads signaling pathway in MDA-231BO cells}

Since TGF- $\beta /$ Smad family signaling is involved in the malignant progression of breast cancer, we set out to investigate the gene expression of these proteins in MDA-231BO cells as well as the effect of osthole on their expression. We found that osthole significantly decreased the expression of TGF- $\beta 1$ and Smad 4, and increased Smad 7 expression in MDA-231BO cells (Figure 6A-6C). We then further examined the regulation of osthole on TGF- $\beta$-induced cell viability and migration. Cells were pretreated with $2 \mathrm{ng} / \mathrm{mL}$ TGF- $\beta 1$ for $3 \mathrm{~h}$, and then incubated with the indicated concentrations of osthole. We initiated the MTT and wound healing assay after $24 \mathrm{~h}$ of treatment with or without osthole, and imaged the representative scrape lines. Although TGF- $\beta$ actually promotes the proliferation and / or migration of cancer breast cancer cells, the effects of TGF- $\beta$ on
A

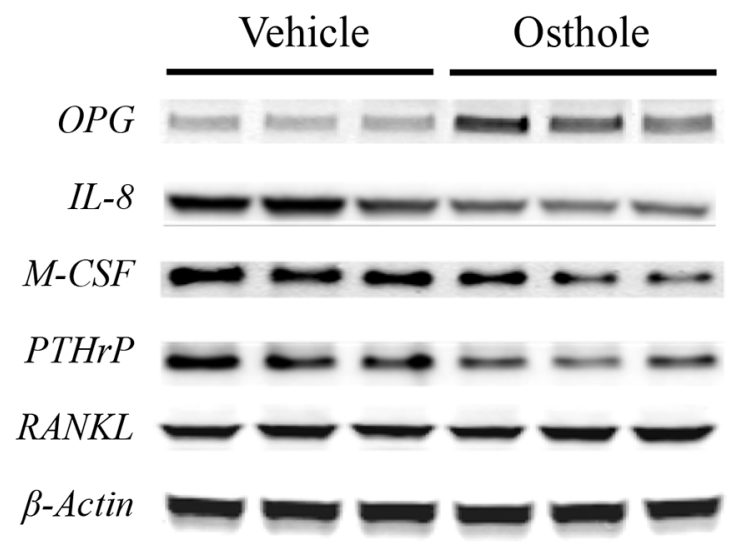

C

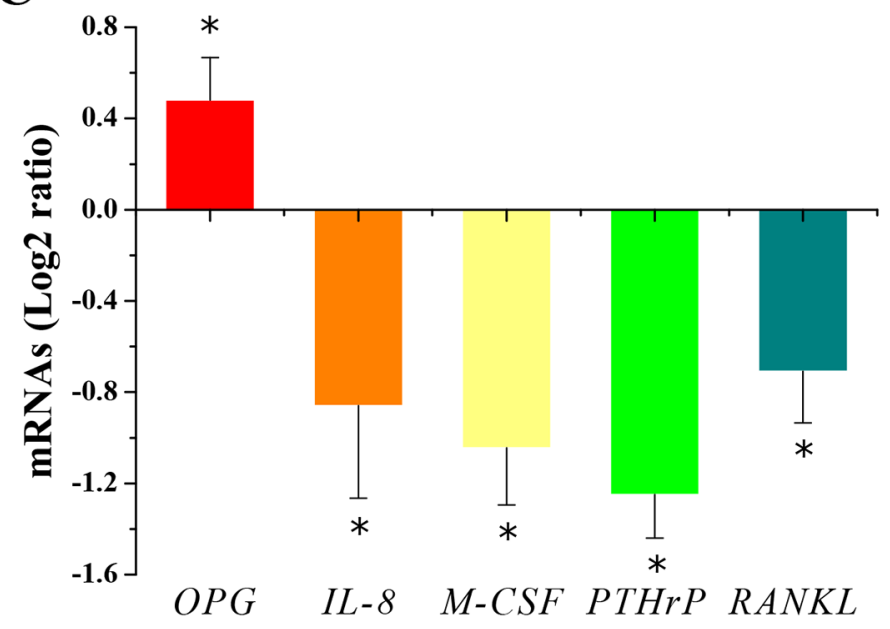

B

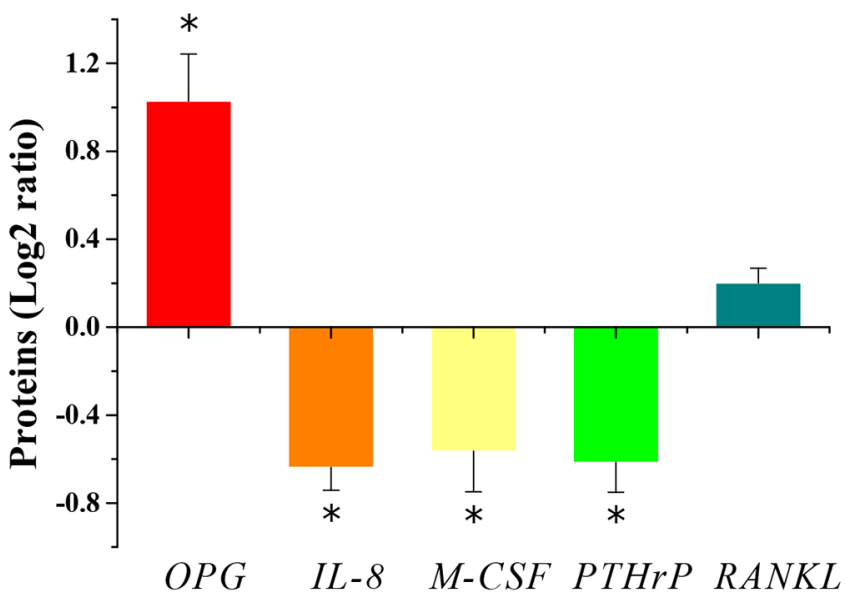

Figure 2: Alteration of bone metastatic and / or bone-related gene expression in osseous metastases. (A) Representative images of protein expression by western blotting ( $\mathrm{n}=3$ for each group). (B) Quantitative results of protein expression were made by two image analysis experts using Image $J$ software (National Institutes of Health, Bethesda, MD, USA) (log2-ratio vs. vehicle; mean \pm SD). $* \mathrm{p}<0.05$ vs. vehicle. (C) Quantitative results of mRNA expression determined with RT-qPCR. RT-qPCR measurements (log2-ratio vs. vehicle; mean $\pm \mathrm{SD}$ ) in 6 individual mRNA samples obtained from bone metastasis lesions with or without osthole treatment. * $\mathrm{p}<0.05 \mathrm{vs}$. vehicle. Mice were sacrificed at the end of treatment, and metastatic bone lesions were harvested and stored in liquid nitrogen. Frozen tissue was homogenized with a pestle and total RNA and protein were extracted for RT-qPCR and western blotting, respectively. 
breast cancer line MDA-MB-231 and its subclone MDA$231 \mathrm{BO}$ are different with respect to other cell lines [24]. Additionally, TGF- $\beta$ profoundly inhibited MDAMB-231 cell growth, but did not have any inhibitory or proliferative effects on MDA-231BO cell growth [24]. Consistent with previous studies, we found that TGF- $\beta$ did not promote MDA-231BO cell viability and cell migration (Figures 4A, 6D/6E). Ironically, our data suggested that osthole could inhibit wound healing in breast cancer cell line MDA-231BO pre-treated with TGF- $\beta$ (Figure $6 \mathrm{E} / 6 \mathrm{~F}$ ). Taken together, osthole probably regulated TGF- $\beta /$ Smads signaling to inhibit breast cancer metastasis to bone.

\section{DISCUSSION}

In the current study, osthole treatment resulted in a significant decrease in both the proliferation and
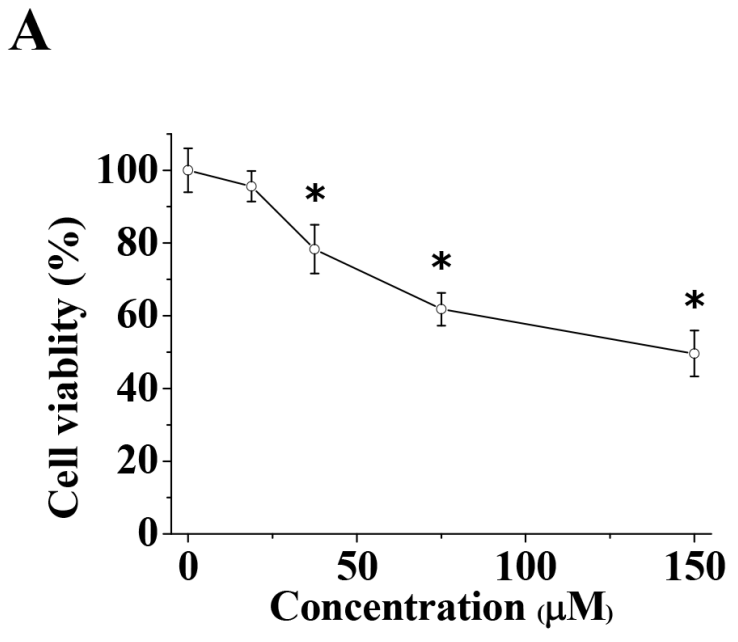

B

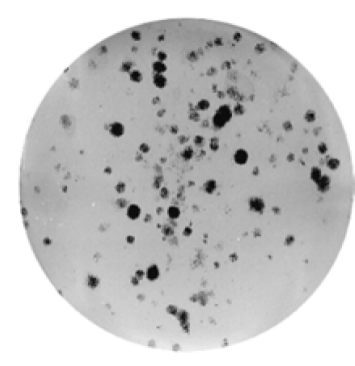

Vehicle

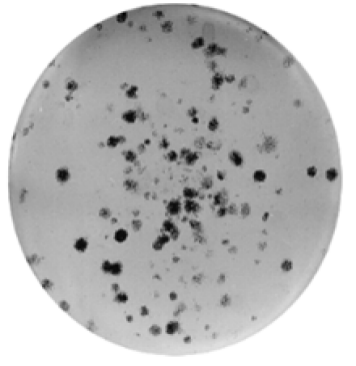

$20 \mu \mathrm{M}$ Osthole

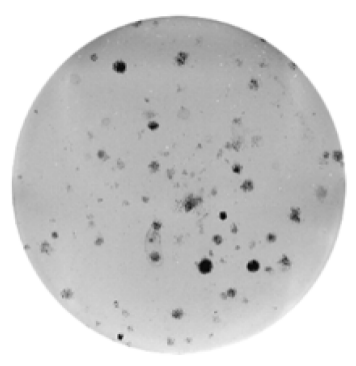

$40 \mu \mathrm{M}$ Osthole

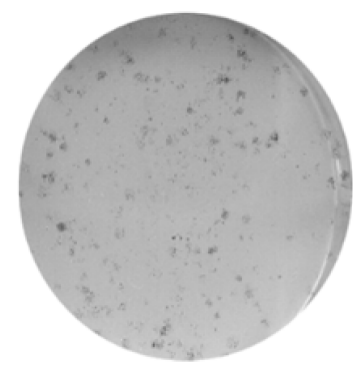

$80 \mu \mathrm{M}$ Osthole

Figure 3: Osthole inhibited breast cancer cell viability and proliferation. (A) Osthole treatment inhibited MDA-231BO cell viability. Cells were treated with vehicle or osthole $(18.75,37.5,75$ and $150 \mu \mathrm{M})$ for $24 \mathrm{~h}$ and then measured using MTT assays. Results are expressed as mean $\pm \mathrm{SD}$ for three experiments ( $* p<0.05$ by ANOVA). (B) Representative images from colony formation assays using cells treated with either osthole or vehicle were taken at $24 \mathrm{~h}$. (C) Quantitative results of colony formation (\% of vehicle) expressed as the mean \pm SD of three experiments. $* \mathrm{p}<0.05$ vs. vehicle. Colony formation of vehicle-treated cells was set at $100 \%$, and values for colony formation of osthole-treated cells were represented as a percentage of vehicle colony formation ( $* x<0.05$ by ANOVA). 

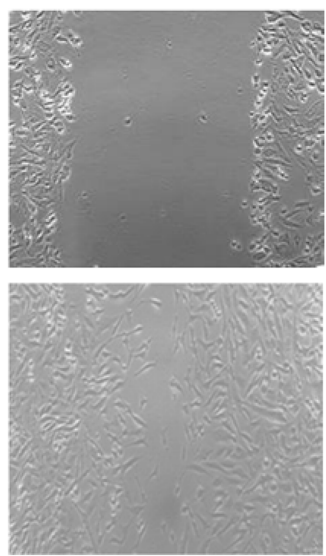

Vehicle
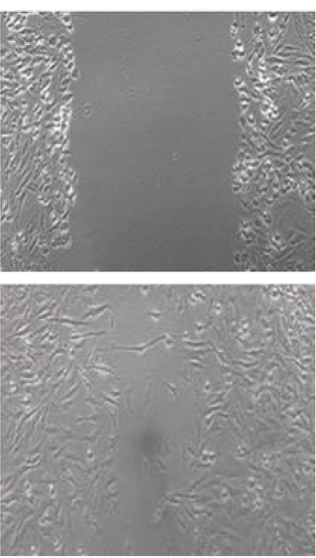

$20 \mu \mathrm{M}$ Osthole
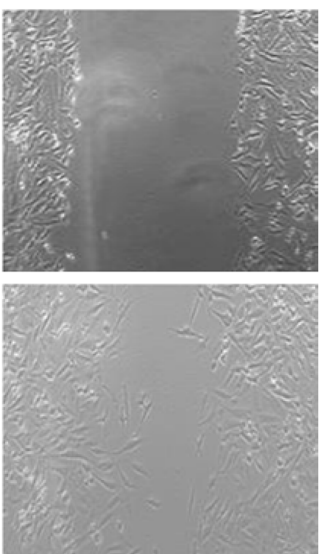

$40 \mu \mathrm{M}$ Osthole

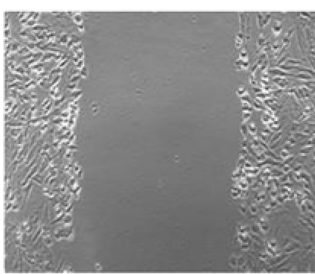

O h

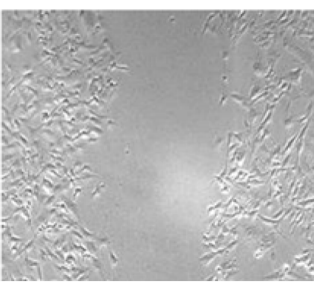

$80 \mu \mathrm{M}$ Osthole

B

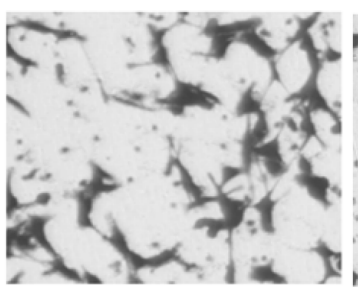

Vehicle

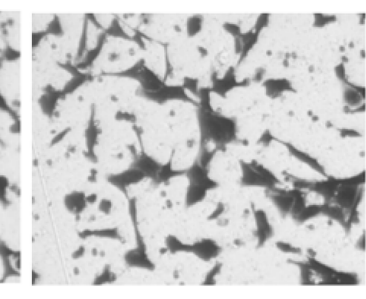

$20 \mu \mathrm{M}$ Osthole

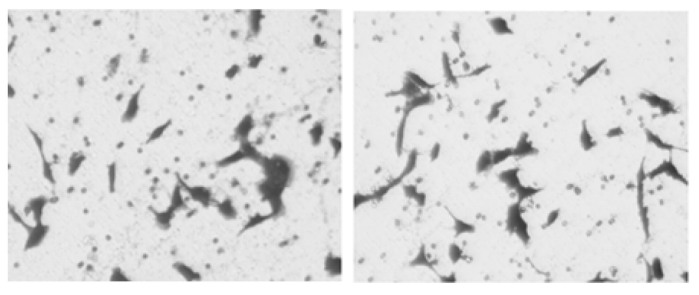

$40 \mu \mathrm{M}$ Osthole
$80 \mu \mathrm{M}$ Osthole

C

D
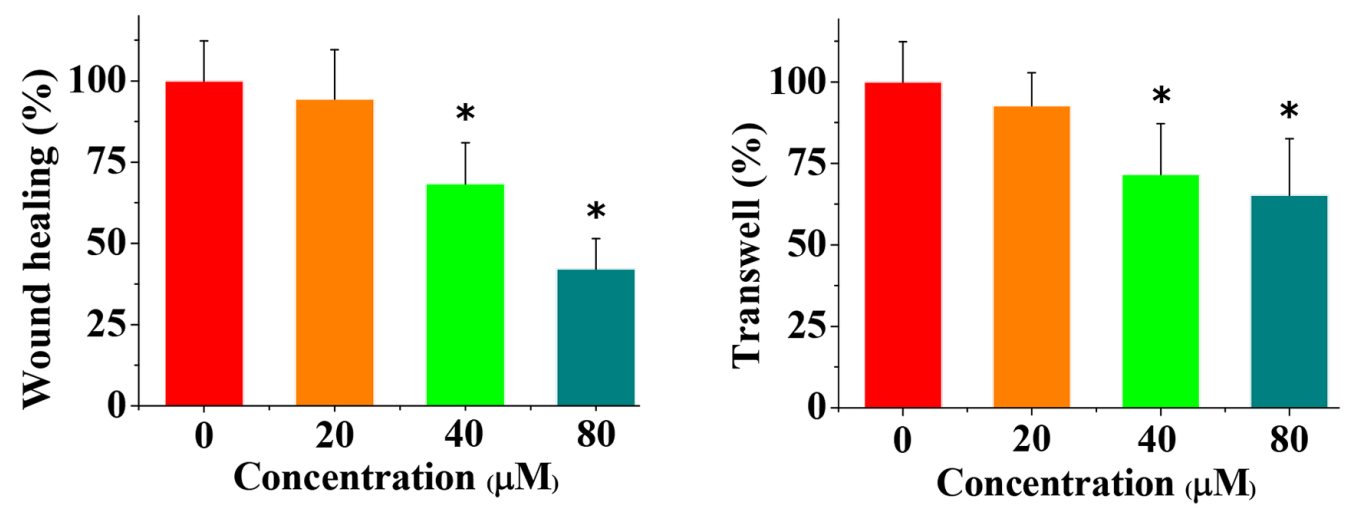

Figure 4: The anti-invasion and anti-migration effects of osthole on breast cancer cells. (A) Representative images from wound healing assays using cells treated with either osthole or vehicle were taken at $0 \mathrm{~h}$ and $24 \mathrm{~h}$. (B) Representative images of transwell analysis of cells treated with either osthole or vehicle were taken at $24 \mathrm{~h}$. (C) Wound closure was quantified as the percentage of wound closure, and expressed as the mean $\pm \mathrm{SD}$ of three experiments. Wound closure of vehicle-treated cells was set at $100 \%$, and wound closure of osthole-treated cells was represented as a percentage of the vehicle wound closure $(* p<0.05$ by ANOVA). (D) Quantitative results of transwell migration assay ( $\%$ of vehicle) expressed as the mean $\pm \mathrm{SD}$ of three experiments. $* \mathrm{p}<0.05$ vs. vehicle. Transwell assay data, with vehicle-treated cells set at $100 \%$, and osthole-treated cells represented as a percentage of the vehicle group $(* p<0.05$ by ANOVA). 
was a consequence of reduced cellular viability and proliferation, we used MTT and colony formation assays. We found that, osthole significantly reduced the viability of MDA-231BO cells and inhibited cell proliferation. The results of wound healing and transwell analyses also showed that osthole significantly decreased cell migration and invasion. In addition, we observed that osthole significantly decreased tumor infiltration and reduced cancer cell proliferation in tumor-bearing mice. Furthermore, we found that osthole also induced apoptosis in MDA-231BO cells. Considering these results along with those from previous studies [15, 20, 23], we believe that osthole's inhibition of breast cancer cells in vitro and in vivo may depend, not only on antiproliferative effects, but also on antimigratory and apoptosis-inducing effects.

Bone homeostasis is a highly regulated balance between osteoblastic bone formation and osteoclastic bone resorption. Many molecular mediators have been implicated in this balance, such as OPG, RANK, RANKL, PTHrP, M-CSF and IL-8 [25]. Previous studies have demonstrated that osthole suppresses bone loss and promotes bone healing though regulating the differentiation of osteoblasts and osteoclasts [21, 22]. In our present study, osthole increased the expression of OPG and decreased the expression of IL-8, M-CSF,
PTHrP, and RANKL in osseous metastases. Recently, Zhai et al showed that osthole enhances bone formation and inhibits bone resorption [26]. The authors verified that osthole decreases RANKL mRNA expression and stimulates mRNA expression of OPG in rat calvarial osteoblasts and bone marrow stromal cells. In addition, they also showed that osthole inhibits osteoclastic bone resorption via the regulation of TRAP activity. Taken together, these data and previous studies $[21,22,26]$ support the hypothesis that osthole inhibits osteoblastic RANKL expression as well as differentiation of osteoclast precursors to osteoclasts in vitro. Collectively, these results indicated that osthole inhibits interactions among cancer cells, osteoblasts, and osteoclasts in osseous lesions.

The TGF- $\beta /$ Smad family pathway plays a critical in breast cancer bone metastasis $[27,28]$. The TGF- $\beta$ released from the bone matrix as a result of increased bone resorption can act on tumor cells. This interaction causes the tumor cells to produce factors such as PTHrP and IL11 , resulting in further osteoclastogenesis and perpetuation of osteolytic disease [29]. In the present study, we found that osthole altered TGF- $\beta$ and Smad levels in breast cancer MDA-231BO cells. We then examined the inhibitory effect of osthole on TGF- $\beta$-induced cell viability and migration. We found that, in MDA-231BO cells,
A

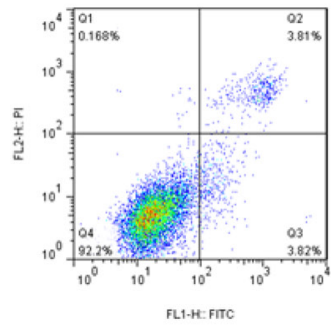

Vehicle

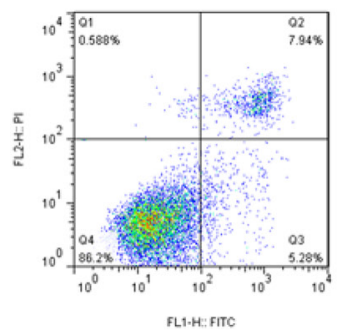

$40 \mu \mathrm{M}$ Osthole

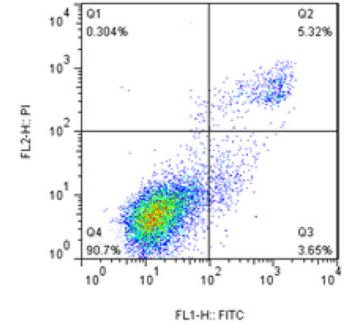

$20 \mu \mathrm{M}$ Osthole

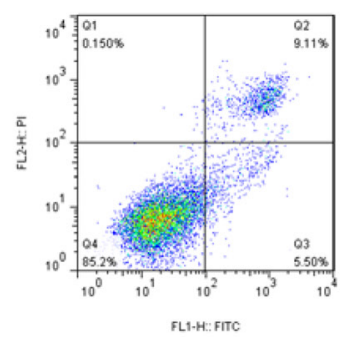

$80 \mu \mathrm{M}$ Osthole
B

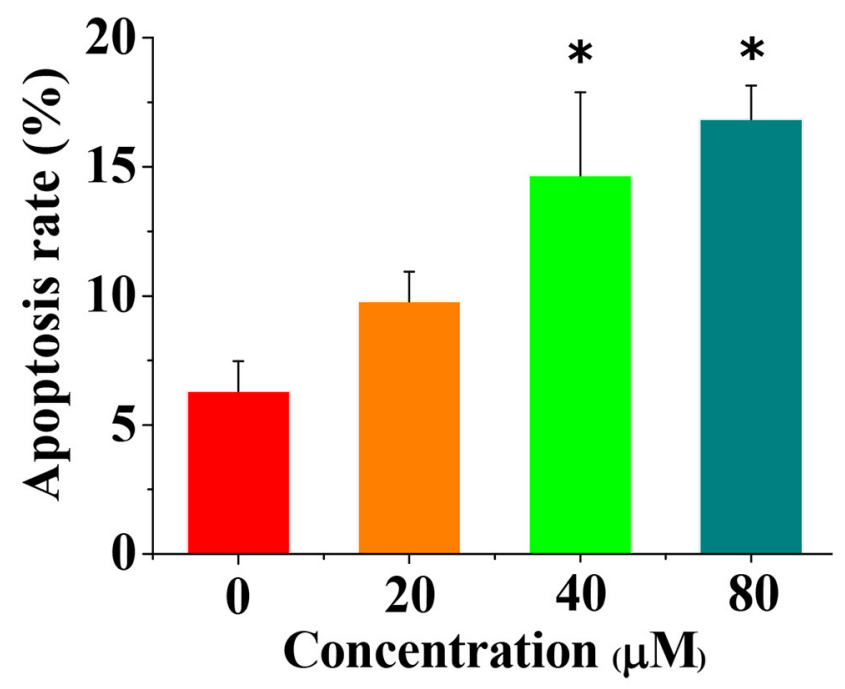

Figure 5: Osthole induced breast cancer cells apoptosis. (A) Representative flow cytometry analysis data from Annexin V-FITC/ PI staining. Cell apoptosis levels from cells treated with either osthole or vehicle were assessed at $24 \mathrm{~h}$. (B) Quantitative results of cell apoptosis determined using Annexin V-FITC/PI flow cytometry analysis and expressed as the mean \pm SD of three experiments. ${ }^{*} \mathrm{p}<0.05$ vs. vehicle. 

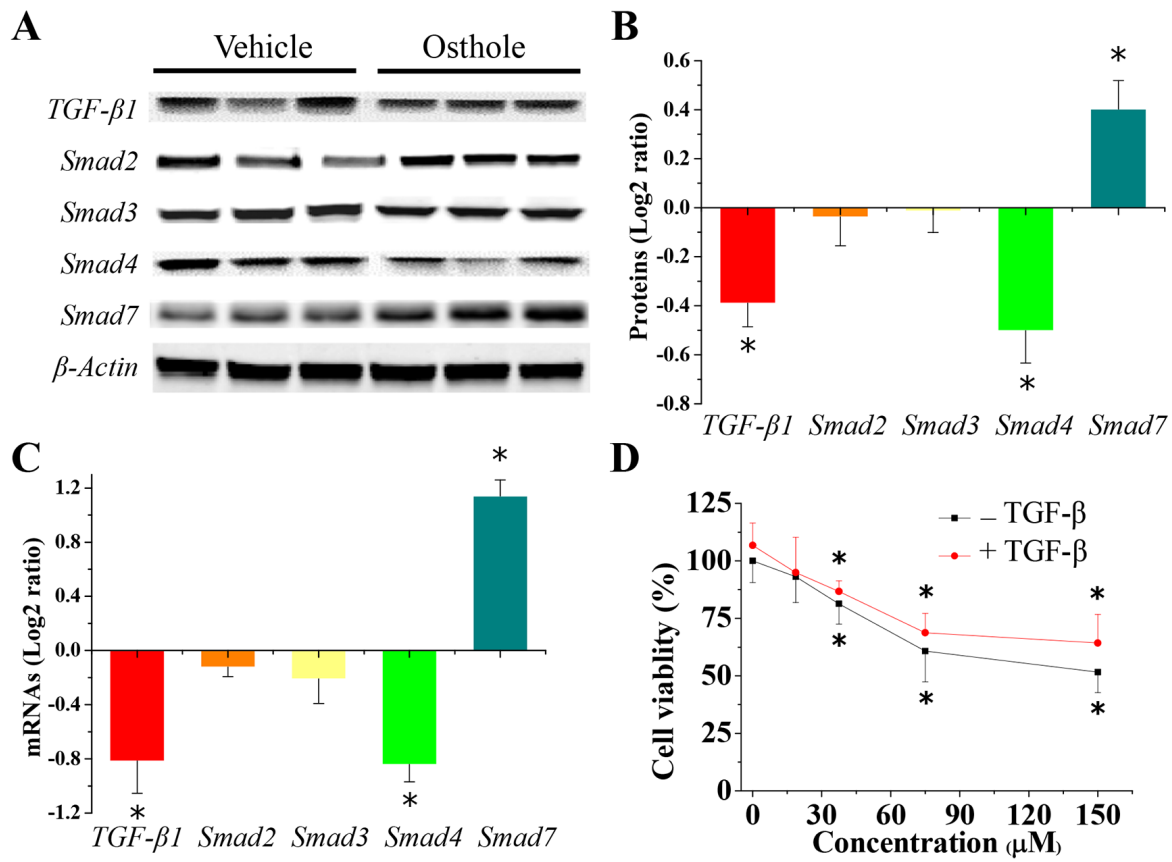

D

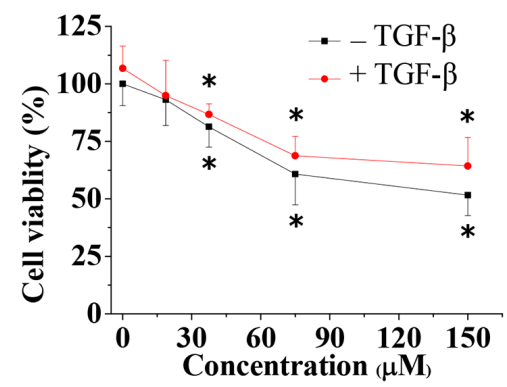

$\mathbf{E}$

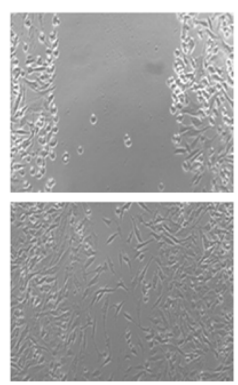

Vehicle
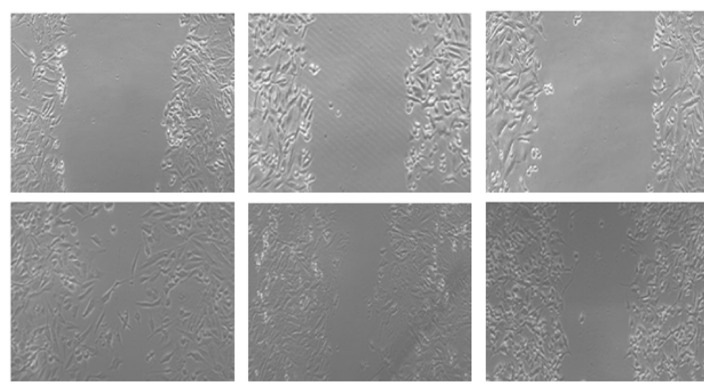

$40 \mu \mathrm{M}$ Osthole

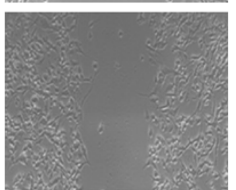

$80 \mu \mathrm{M}$ Osthole

O h

$24 \mathrm{~h}$

F

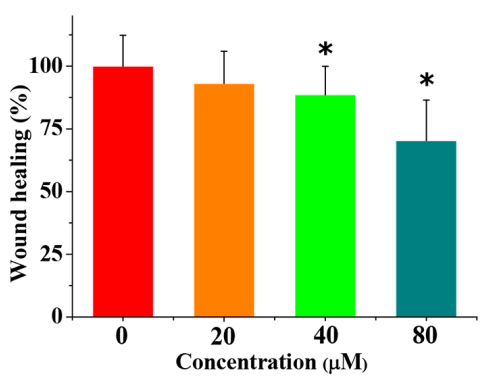

Figure 6: Alteration in gene expression of TGF- $\beta$ /Smads signal pathway. (A) Representative images of protein expression detected by western blotting. Cells were treated with or without $80 \mu \mathrm{M}$ osthole for $24 \mathrm{~h}$. Protein lysates were separated by SDS-PAGE and subjected to western blotting analysis using the specific antibodies indicated. (B) Quantification of the results of the protein expression ( $\log 2$-ratio vs. vehicle; mean $\pm \mathrm{SD}$ ). Scanning densitometry was used for semiquantitative analysis for comparison to the vehicle-treated group. Results are expressed as the mean \pm SD from three experiments. ${ }^{*} \mathrm{p}<0.05$ vs. vehicle. (C) Osthole-regulated TGF- $\beta$ and Smad family gene expression. Cells were treated with or without $80 \mu \mathrm{M}$ osthole for $24 \mathrm{~h}$. Cells were collected and total RNA was extracted and analyzed using RT-qPCR. Measurements for RT-qPCR (log2-ratio vs. vehicle; mean \pm SD) in 6 individual mRNA samples obtained from MDA-231BO cells treated with or without osthole. ${ }^{*} \mathrm{p}<0.05$ vs. vehicle. (D) Osthole treatment inhibited MDA-231BO cell viability when pretreated with TGF- $\beta 1$. Cells were pretreated with $2 \mathrm{ng} / \mathrm{mL}$ TGF- $\beta 1$ for $3 \mathrm{~h}$, then were treated with indicated concentration of osthole for $24 \mathrm{~h}$, and finally were measured by MTT assays. Results are expressed as mean \pm SD for three experiments $(* p<0.05$ by ANOVA). (E) Representative images from wound healing assays using cells treated with either osthole or vehicle were taken at $0 \mathrm{~h}$ and $24 \mathrm{~h}$, when pretreated with TGF- $\beta 1$. Cells were pretreated with $2 \mathrm{ng} / \mathrm{mL}$ TGF- $\beta 1$ for $3 \mathrm{~h}$, and then incubated with or without the indicated concentrations of osthole. After $24 \mathrm{~h}$ treatment with or without osthole, wound healing assays were begun, and representative scrape lines were imaged. (F) Wound closure was quantified as percentage of the wound closure from the control group, and expressed as the mean \pm $\mathrm{SD}$ of three experiments. ( $* p<0.05$ by ANOVA). 
osthole significantly inhibited cell viability and migration when pro-treated with or without TGF- $\beta 1$. Interestingly, these results supported the hypothesis that osthole and its derivatives can effectively reduce dysfunctional TGF- $\beta$ / Smads signaling [30]. These findings, backed by previous studies $[20,30]$, indicated that osthole regulates TGF- $\beta$ signaling in breast cancer metastasis to bone in MDA$231 \mathrm{BO}$ cells.

Our results demonstrated that osthole significantly reduced bone metastasis and decreased the total tumor burden of breast cancer metastases in mice. In combination with previous work $[15,20-23,26,30]$, these findings suggest that osthole may potentially act on advanced breast cancer cells through the regulation of cellular viability, proliferation, migration, invasion, and apoptosis as well as through the interactions of osteoblasts, osteoclasts, and cancer cells during breast cancer bone metastasis (Figure 7). Therefore, osthole might have potential as a viable therapeutic candidate for the treatment of breast cancer patients with bone metastases.

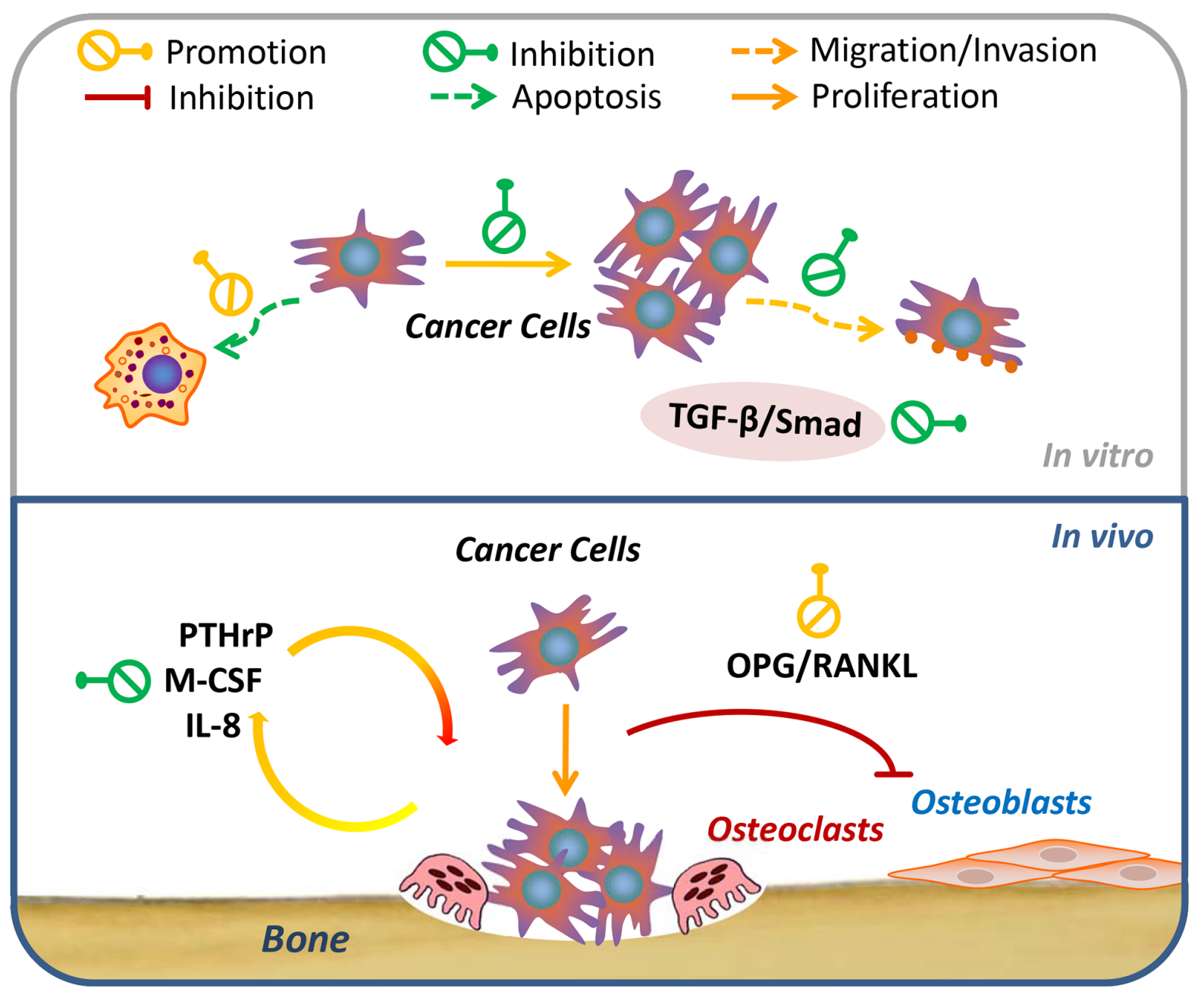

Figure 7: Schematic representation of the signaling pathways probably involved in osthole-mediated breast cancer bone metastasis. Osthole inhibited breast cancer cell growth, migration, and invasion, and induced apoptosis of breast cancer cells in vitro. Additionally, it probably regulated TGF- $\beta /$ SMADs signaling in the metastasis of breast to bone cancer in MDA-231BO cells. Besides, it also altered pro-metastatic / bone metabolic genes and regulated OPG/RANKL signals in the interactions between bone cells (osteoblasts and osteoclasts) and cancer cells in vivo. The green and yellow symbols indicate the inhibitory and promoting effects of osthole, respectively. Abbreviations: IL-8, interleukin-8; M-CSF, macrophage colony-stimulating factor; OPG, osteoprotegerin; PTHrP, parathyroid hormone-related peptide; RANKL, receptor activator of nuclear factor kappa-B ligand; TGF- $\beta$, transforming growth factor-beta. 
Table 1: Primer sequences used in real-time quantitative PCR analysis

\begin{tabular}{|c|c|c|c|c|}
\hline \multirow[t]{2}{*}{ Type } & \multirow[t]{2}{*}{ Name } & \multicolumn{2}{|r|}{ Primer } & \multirow{2}{*}{$\begin{array}{l}\text { Annealing temperature } \\
\left({ }^{\circ} \mathrm{C}\right)\end{array}$} \\
\hline & & Type & Sequence, 5'-3' & \\
\hline \multirow[t]{12}{*}{ Mice } & IL-8 & Sense & ACA TGA CTT CCA AGC TGG CCG T & 52 \\
\hline & & Antisense & ССТ СТT CAA AАA СТТ СТC CAC AАC & \\
\hline & M-CSF & Sense & AGC AGG AGT ATC ACC GAG GA & 52 \\
\hline & & Antisense & TAT CTC TGA AGC GCA TGG TG & \\
\hline & PTHrP & Sense & ATG CAG CGG AGA CTG GTT CAG & 58 \\
\hline & & Antisense & TTC TAG TGC CAC TGC CCA TTG & \\
\hline & OPG & Sense & CTT CGT GCC TTG ATG GA & 44 \\
\hline & & Antisense & TTG GGA AAG TGG GAT GT & \\
\hline & RANKL & Sense & ACC AAG ATG GCT TCT ATT ACC & 44 \\
\hline & & Antisense & TCC CTC CTT TCA TCA GGT TAT & \\
\hline & GAPDH & Sense & GGT CGG AGT CAA CGG ATT TG & 58 \\
\hline & & Antisense & ATG AGC CCC AGC CTT CTC CAT & \\
\hline \multirow[t]{12}{*}{ Cell } & TGF- $\beta 1$ & Sense & AGC GAC TCG CCA GAG TGG TTA & 58 \\
\hline & & Antisense & GCA GTG TGT TAT CCC TGC TGT CA & \\
\hline & Smad 2 & Sense & TTA ACC GAA ATG CCA CGG TAG AA & 60 \\
\hline & & Antisense & GCT CTG GAC AAA CAT TGC ACT ATC A & \\
\hline & Smad 3 & Sense & AGG CGT GCG GCT CTA CTA CAT C & 60 \\
\hline & & Antisense & CAG CGA ACT CCT GGT TGT TGAA & \\
\hline & Smad 4 & Sense & CAG CAC TAC CAC CTG GAC TGG A & 60 \\
\hline & & Antisense & CTG GAA TGC AAG CTC ATT GTG AA & \\
\hline & Smad 7 & Sense & TGC TGT GCA AAG TGT TCA GGT G & 60 \\
\hline & & Antisense & CCA TCG GGT ATC TGG AGT AAG GA & \\
\hline & GAPDH & Sense & GCA CCG TCA AGG CTG AGA AC & 58 \\
\hline & & Antisense & TGG TGA AGA CGC CAG TGG A & \\
\hline
\end{tabular}

\section{MATERIALS AND METHODS}

\section{Materials}

Osthole (purity $>98 \%$ ) was purchased from the National Institutes for Food and Drug Control, China. L-15 media and fetal bovine serum were obtained from Gibco (Grand Island, New York, USA). Antibodies against osteoprotegerin (OPG), receptor activator of nuclear factor kappa-B ligand (RANKL), macrophage colony-stimulating factor (M-CSF), parathyroid hormonerelated peptide (PTHrP) and transforming growth factorbeta 1 (TGF- $\beta 1$ ) were all obtained from Santa Cruz Biotechnology Biotechnology (Santa Cruz, CA). The antibody against interleukin-8 (IL-8) was purchased from Abcam Technology (Cambridge, MA). Smad 2, Smad 3 and Smad 4 antibodies were obtained from Cell Signaling
Technology (Danvers, MA, USA). Smad 7 antibody was purchased from R\&D Systems (USA). Nitro blue tetrazolium (NBT) and the 5-bromo-4-chloro-3-indolyl phosphate (BCIP) Color Development bone scintigraphy substrate were obtained from Promega Biotech (Madison, Wisconsin, USA). All other chemicals were purchased from Sigma-Aldrich (Saint Louis, Missouri, USA) unless otherwise indicated.

\section{Animals and experimental procedure}

Female nude $(\mathrm{BALB} / \mathrm{c} n u / n u)$ mice $(20 \pm 2 \mathrm{~g}$; Shanghai Cancer Institute of Shanghai Jiaotong University) were housed in a temperature-controlled (24 $\pm 2^{\circ} \mathrm{C}$ ) room with a regular 12 -h light/dark cycle. After one week of acclimatization in a specific pathogen-free (SPF) environment, animals were randomly assigned 
to one of several experimental groups. All animals had free access to water and food until the day before the experiment. All animals had free access to food and water until the day prior to the experiment. All experiments were performed in accordance with national regulations for animal experimentation and approved by the Institutional Animal Care and Use Committee of the Shanghai Chest Hospital of Shanghai Jiaotong University (Permit Number: 20120219003).

Mice received an intracardiac injection of MDA$231 \mathrm{BO}$ cells, resulting in osseous metastases as detected by radionuclide bone scintigraphy and X-ray imaging within 2 weeks of tumor inoculation. The mice were then randomly divided into 2 groups ( $n=10$ per group) that received either oral osthole $(5.25 \mathrm{mg} / \mathrm{kg})$ or vehicle twice weekly for 6 weeks. Every two weeks following inoculation, bone metastasis was evaluated by in vivo imaging with radiographs and radionuclide bone scintigraphy. Mice were sacrificed at the end of treatment, and metastatic bone lesions, observed by radionuclide scintigraphy and radiography, were sectioned and sent for H\&E staining (magnification: 200X).

\section{Cell lines and cell culture}

MDA-231BO cells were cultured in L-15 medium supplemented with $10 \%(\mathrm{v} / \mathrm{v})$ fetal bovine serum at $37^{\circ} \mathrm{C}$ in a humidified atmosphere containing 5\% $\mathrm{CO}_{2}$. Cells were washed three times and placed in sterile phosphatebuffered saline (PBS) shortly before implantation. An exclusive bone metastatic subclone, termed MDA-231BO, was acquired through repeatedly injecting MDA-231 breast cancer cells into the left ventricle and isolating tumor cells from bone metastasis lesions [31]. While the parental line (MDA-231) can develop metastases in bone, brain, ovary, and adrenal glands, MDA-231BO almost exclusively metastasizes to bone [24].

\section{Cell viability assay}

Dose-response curves were determined using MTT assays. Cells $\left(1 \times 10^{5}\right.$ cells $\left./ \mathrm{mL}\right)$ were seeded in 96-well plates and incubated for $12 \mathrm{~h}$. Osthole was diluted to the appropriate concentration and immediately added to the media. After 24 $\mathrm{h}$ of treatment, cell viability was evaluated by cell-mediated MTT reduction. Optical densities were detected at $570 \mathrm{~nm}$.

\section{Colony formation assay}

Cells were seeded in 6-well plates at a density of 500 cells per well, and after 10 days, the colonies with a diameter of $>0.05 \mathrm{~mm}$ were counted.

\section{Wound healing assay}

Cells were seeded in 6-well plates at a total of $8 \times$ $10^{4}$ cells per well, and when cellular confluence reached about $90 \%$, a $200 \mu \mathrm{l}$ pipette tip was used to create wounds in the confluent cells. Wells were then rinsed with medium to remove any free-floating cells and debris, and media without serum containing various concentrations of osthole was added. Within $24 \mathrm{~h}$ after the scrape line was made, wound healing was observed and representative scrape lines were imaged. The percentage of wound area was calculated as follows: wound area $(\%)=$ (original wound area ${ }_{\text {treated }}$ - remaining wound area treated $) /$ original wound area ${ }_{\text {vehicle }}$ - remaining wound area vehicle $) \times 100$. Each assay was conducted in triplicate.

\section{Transwell assay}

MDA-231BO cells were seeded into transwell inserts at $5 \times 10^{4}$ cells using 24-well transwell chambers (Corning) separated by a polycarbonate filter coated with $50 \mu \mathrm{g} / \mathrm{ml}$ collagen IV, with or without osthole at the indicated concentrations. After $24 \mathrm{~h}$, cells on the top side of the inserts were scraped off and the transwell filters were stained with crystal violet and examined under an inverted microscope. The cells that had migrated within $24 \mathrm{~h}$ were quantified from triplicate wells.

\section{Apoptosis detection assay}

A flow cytometric assay was performed to assess the effects of osthole on cell apoptosis as previously described [32]. Briefly, MDA-231BO cells were treated with osthole for $24 \mathrm{~h}$, and then cells were harvested, and single-cell suspensions were prepared and stained with Annexin V-FITC/PI for apoptosis analysis. Cells were assessed using a Becton Dickinson FACScalibur machine and data were analyzed using CellQuest.

\section{Intracardiac injection}

Intracardiac injections were performed as described previously [33]. Briefly, cells were resuspended at $10^{6}$ cells $/ \mathrm{mL}$ in PBS. Suspended cells $(0.1 \mathrm{~mL})$ were injected into the left ventricle using 29 gauge needles (Terumo, Tokyo, Japan).

\section{Radionuclide bone scintigraphy}

Radionuclide bone scintigraphy analyses were performed as described previously [33]. Following inoculation, bone metastasis was evaluated by in vivo imaging with radionuclide bone scintigraphy in 2-week intervals.

\section{Radiographic imaging}

Radiographic imaging analyses were performed as described previously [33]. Briefly, conventional radiographs were obtained using a Philips Optimus Bucky Diagnost TS X-ray System (Philips Healthcare, 
Eindhoven, Netherlands). The X-ray tube voltage was fixed at $40 \mathrm{kVp}$, the current at $2 \mathrm{~mA}$, and the exposure time at $3 \mathrm{~s}$.

\section{Histology}

After radionuclide scintigraphy and radiography analyses identified the bones with metastatic lesions, sample tissues were dissected, sectioned, and stained with hematoxylin and eosin (H\&E). Histological evaluation of metastasis lesions was performed as described in our previous work [31]. Briefly, cancer cells were identified, and the percentage of cancer cells per high-power field-ofview (400× magnification) was calculated. All histological sections were examined by two independent pathologists. Sections that received substantially different scores from the two pathologists ( $>5 \%$ discrepancy) were reviewed again until a consensus was reached.

\section{Real-time quantitative PCR}

Metastatic bone lesions were harvested and stored in liquid nitrogen. Frozen tissue $(0.2-0.25 \mathrm{~g})$ was homogenized with a pestle, and total RNA was extracted with TRIZOL reagent (Promega, Madison, WI) according to the manufacturer's instructions. Realtime PCR was performed as described in our previous work [33]. Primers were obtained from Shanghai Sangon Biological Engineering Technology \& Services Co., Ltd. (Shanghai, China), and their sequences are shown in Table 1. The cycling conditions included an initial polymerase activation for $3 \mathrm{~min}$ at $94^{\circ} \mathrm{C}$ followed by 40 cycles of denaturation at $94^{\circ} \mathrm{C}$ for $30 \mathrm{~s}$, annealing for 40 $\mathrm{s}$ at the temperatures indicated in Table 1, and elongation at $72^{\circ} \mathrm{C}$ for $30 \mathrm{~s}$. RT-qPCR results for expression level were obtained using the delta delta CT method, by taking the threshold cycle number (CT) and, normalizing to the housekeeping gene, glyceraldehyde 3-phosphate dehydrogenase (GAPDH), then comparing relative to the vehicle. Finally, the values of each group were transformed to $\log 2$ ratio. $\mathrm{P}$ values were calculated using a $t$-test.

\section{Western blotting}

Frozen tissues $(0.2-0.25 \mathrm{~g})$ were homogenized using a pestle. Total protein was extracted and normalized, and western blot assays were performed as described previously with slight modifications [33]. Briefly, equal amounts of protein $(20 \mu \mathrm{g})$ were separated by SDS-PAGE and transferred to nitrocellulose membranes. Membranes were blocked with $2 \%$ BSA and then incubated with the appropriate primary antibodies overnight at $4^{\circ} \mathrm{C}$. Protein expression was detected by staining with NBT and BCIP. $\beta$-Actin was used as a loading control. Two imaging analysis experts have independently analyzed and quantified the immunoblotting data using Image $\mathbf{J}$ software (National Institutes of Health, Bethesda, MD, USA).
The quantitative results generated by these two experts differed substantially ( $>5 \%$ discrepancy) and were further analyzed until an agreement was reached. The data were then normalized to the vehicle group. Finally, the values of each group were transformed to $\log 2$ ratio. $\mathrm{P}$ values were calculated using a $t$-test.

\section{Statistical analyses}

All results are presented as mean \pm standard deviation (SD). Two-tailed analysis of variance (ANOVA), followed by Dunnett's post hoc test and Fisher's test were used to determine the statistical significance. A $p$ value $<$ 0.05 was considered significant for all tests.

\section{Abbreviations}

BCIP, 5-bromo-4-chloro-3-indolyl phosphate; C. monnieri, Cnidium monnieri (L.) Cusson; IL-8, interleukin-8; M-CSF, macrophage colony-stimulating factor; NBT, nitro blue tetrazolium; OPG, osteoprotegerin; PTHrP, parathyroid hormone-related peptide; RANKL, receptor activator of nuclear factor kappa-B ligand; RTqPCR, real-time quantitative PCR; TGF- $\beta$, transforming growth factor- $\beta$.

\section{ACKNOWLEDGMENTS}

This research was supported by The National Natural Science Foundation of China (No. 81603629), Natural Science Foundation of Shanghai (No. 17ZR1430700 and 17ZR1430900), and Shanghai Municipal Commission of Health and Family Planning (No.20164Y0064).

\section{CONFLICTS OF INTEREST}

The authors declare no potential conflicts of interest.

\section{REFERENCES}

1. Chen J, Chiou WF, Chen CC, Chen CF. Effect of the plant-extract osthole on the relaxation of rabbit corpus cavernosum tissue in vitro. J Urol. 2000; 163: 1975-80.

2. Meng F, Xiong Z, Sun Y, Li F. Coumarins from Cnidium monnieri (L.) and their proliferation stimulating activity on osteoblast-like UMR106 cells. Pharmazie. 2004; 59: 643-5.

3. Zhang Q, Qin L, He W, Van Puyvelde L, Maes D, Adams A, Zheng H, De Kimpe N. Coumarins from Cnidium monnieri and their antiosteoporotic activity. Planta Med. 2007; 73: 13-9.

4. Qin LP, Zhang QY, Tian YP, Zheng HC, Huang M, Huang BK. Total coumarins from fruits of Cnidium monnieri inhibit formation and differentiation of multinucleated osteoclasts of rats. Acta Pharmacol Sin. 2003; 24: 181-6.

5. Liu $\mathrm{S}, \mathrm{Wu} \mathrm{C}, \mathrm{Chen} \mathrm{X}$. Inhibitory acting mechanism of psoralen-osthole on bone metastasis of breast cancer: an 
expatiation viewing from OPG/RANKL/RANK system. Zhongguo Zhong Xi Yi Jie He Za Zhi. 2011; 31: 684-9.

6. Han XH, Wang CL, Xie Y, Ma J, Zhang XH, Hu QW, Lin G, Liu S, Lu JG. Anti-metastatic effect and mechanisms of Wenshen Zhuanggu formula in human breast cancer cells. J Ethnopharmacol. 2015; 162: 39-46.

7. Matsuda H, Tomohiro N, Ido Y, Kubo M. Anti-allergic effects of cnidii monnieri fructus (dried fruits of Cnidium monnieri) and its major component, osthol. Biol Pharm Bull. 2002; 25: 809-12.

8. Liao PC, Chien SC, Ho CL, Wang EI, Lee SC, Kuo YH, Jeyashoke N, Chen J, Dong WC, Chao LK, Hua KF. Osthole regulates inflammatory mediator expression through modulating $\mathrm{NF}-\kappa \mathrm{B}$, mitogen-activated protein kinases, protein kinase $\mathrm{C}$, and reactive oxygen species. $\mathrm{J}$ Agric Food Chem. 2010; 58: 10445-51.

9. Chen X, Pi R, Zou Y, Liu M, Ma X, Jiang Y, Mao X, Hu X. Attenuation of experimental autoimmune encephalomyelitis in C57 BL/6 mice by osthole, a natural coumarin. Eur J Pharmacol. 2010; 629: 40-6.

10. Zhou P, Takaishi Y, Duan H, Chen B, Honda G, Itoh M, Takeda Y, Kodzhimatov OK, Lee KH. Coumarins and bicoumarin from Ferula sumbul: anti-HIV activity and inhibition of cytokine release. Phytochemistry. 2000; 53: 689-97.

11. Liang HJ, Suk FM, Wang CK, Hung LF, Liu DZ, Chen NQ, Chen YC, Chang CC, Liang YC. Osthole, a potential antidiabetic agent, alleviates hyperglycemia in $d b / d b$ mice. Chem Biol Interact. 2009; 181: 309-15.

12. Sun F, Xie M, Zhu L, Xue J, Gu Z. Inhibitory effect of osthole on alcohol-induced fatty liver in mice. Dig Liver Dis. 2009; 41: 127-33.

13. Ji HJ, Hu JF, Wang YH, Chen XY, Zhou R, Chen NH. Osthole improves chronic cerebral hypoperfusion induced cognitive deficits and neuronal damage in hippocampus. Eur J Pharmacol. 2010; 636: 96-101.

14. Liu WB, Zhou J, Qu Y, Li X, Lu CT, Xie KL, Sun XL, Fei Z. Neuroprotective effect of osthole on $\mathrm{MPP}^{+}$-induced cytotoxicity in PC12 cells via inhibition of mitochondrial dysfunction and ROS production. Neurochem Int. 2010; 57: 206-15.

15. Yang D, Gu T, Wang T, Tang Q, Ma C. Effects of osthole on migration and invasion in breast cancer cells. Biosci Biotechnol Biochem. 2010; 74: 1430-4.

16. Chou SY HC, Wang KT, Wang MC, Wang CC. Antitumor effects of Osthol from Cnidium monnieri: an in vitro and in vivo study. Phytother Res. 2007; 21: 226-30.

17. Okamoto T, Kobayashi T, Yoshida S. Chemical aspects of coumarin compounds for the prevention of hepatocellular carcinomas. Curr Med Chem Anticancer Agents. 2005; 5: 47-51.
18. Yang LL, Wang MC, Chen LG, Wang CC. Cytotoxic activity of coumarins from the fruits of Cnidium monnieri on leukemia cell lines. Planta Med. 2003; 69: 1091-5.

19. Kao SJ, Su JL, Chen CK, Yu MC, Bai KJ, Chang JH, Bien MY, Yang SF, Chien MH. Osthole inhibits the invasive ability of human lung adenocarcinoma cells via suppression

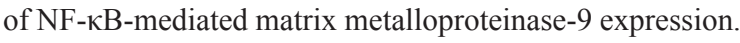
Toxicol Appl Pharmacol. 2012; 261: 105-15.

20. Ye Y, Han X, Guo B, Sun Z, Liu S. Combination treatment with platycodin $\mathrm{D}$ and osthole inhibits cell proliferation and invasion in mammary carcinoma cell lines. Environ Toxicol Pharmacol. 2013; 36: 115-24.

21. Kuo PL, Hsu YL, Chang CH, Chang JK. Osthole-mediated cell differentiation through bone morphogenetic protein-2/ p38 and extracellular signal-regulated kinase $1 / 2$ pathway in human osteoblast cells. J Pharmacol Exp Ther. 2005; 314: 1290-9.

22. Tang DZ, Hou W, Zhou Q, Zhang M, Holz J, Sheu TJ, Li TF, Cheng SD, Shi Q, Harris SE, Chen D, Wang YJ. Osthole stimulates osteoblast differentiation and bone formation by activation of $\beta$-catenin-BMP signaling. J Bone Miner Res. 2010; 25: 1234-45.

23. Wang L, Peng Y, Shi K, Wang H, Lu J, Li Y, Ma C. Osthole inhibits proliferation of human breast cancer cells by inducing cell cycle arrest and apoptosis. J Biomed Res. 2015; 29: 132-8.

24. Yoneda T, Williams P J, Hiraga T, Niewolna M, Nishimura R. A bone-seeking clone exhibits different biological properties from the MDA-MB-231 parental human breast cancer cells and a brain-seeking clone in vivo and in vitro. $\mathrm{J}$ Bone Miner Res. 2001; 16:1486-95.

25. Roodman GD. Mechanisms of bone metastasis. N Engl J Med. 2004; 350: 1655-64.

26. Zhai YK, Pan YL, Niu YB, Li CR, Wu XL, Fan WF, Lu TL, Mei QB, Xian CJ. The importance of the prenyl group in the activities of osthole in enhancing bone formation and inhibiting bone resorption in vitro. Int J Endocrinol. 2014; 2014: 921954. doi: 10.1155/2014/921954.

27. Zhen $G$ and Gao $X$. Targeting TGF $\beta$ signaling in subchondral bone and articular cartilage homeostasis. Trends Pharmacol Sci. 2014; 35: 227-36.

28. Buijs JT, Stayrook KR, Guise TA. The role of TGF- $\beta$ in bone metastasis: novel therapeutic perspectives. Bonekey Rep. 2012; 1: 1-10.

29. Juárez $\mathrm{P}$, Guise TA. TGF- $\beta$ in cancer and bone: implications for treatment of bone metastases. Bonekey Rep. 2011; 48: 23-9.

30. Liu LY, Huang WJ, Ho FM, Lin RJ, Lin SY, Suk FM, Liang YC. N-Hydroxycinnamide derivatives of osthole inhibit cell migration and invasion by suppressing Smad2 and Akt pathways in human colorectal adenocarcinoma cells. Chem Biol Interact. 2014; 217: 1-8. 
31. Wu C, Yang S, Sun Z, Han X, Ye Y, Liu S. Characterization of the attenuation of breast cancer bone metastasis in mice by zoledronic acid using $(99 \mathrm{~m})$ Tc bone scintigraphy. Pathol Oncol Res. 2014; 20: 747-54.

32. Thakur VS, Gupta K, Gupta S. Green tea polyphenols causes cell cycle arrest and apoptosis in prostate cancer cells by suppressing class I histone deacetylases. Carcinogenesis. 2012; 33: 377-84.

33. Wu C, Sun Z, Ye Y, Han X, Song X, Liu S. Psoralen inhibits bone metastasis of breast cancer in mice. Fitoterapia. 2013; 91: 205-10. 